\title{
NT5C2 Gene
}

National Cancer Institute

\section{Source}

National Cancer Institute. NT5C2 Gene. NCI Thesaurus. Code C104587.

This gene plays a role in purine metabolism. 